\title{
RIAU GOVERNMENT'S POLICIES TO REALIZE THE AATHP'S GOALS (2015-2016)
}

\section{Cite as}

Alfajri, A. \& Luerdi, L. (2016). Riau Government's Policies to Realize the AATHP's Goals (20152016). Prosiding Seminar Hasil Penelitian Universitas Abdurrab, 187-198.

https://doi.org/10.5281/zenodo.5830886

Details

Authors: Alfajri and Luerdi

Publication date: November 29, 2016

DOI: $10.5281 /$ zenodo.5830886

Published in: Prosiding Seminar Hasil Penelitian Universitas Abdurrab, Universitas Abdurrab, Pekanbaru, pp. 187-198.

Meeting: Seminar Hasil Penelitian Universitas Abdurrab, Pekanbaru, 29 November 2016 


\title{
RIAU GOVERNMENT'S POLICIES TO REALIZE THE AATHP'S GOALS (2015-2016)
}

\author{
Alfajri ${ }^{1)}$ Luerdi $^{2)}$ \\ 1) Department of International Relations, Universitas Abdurrab \\ J1. Riau Ujung 73, Pekanbaru 28291 Indonesia \\ email : alfajri@univrab.ac.id \\ 2) Department of Internasional Relations, Universitas Abdurrab \\ Jl. Riau Ujung 73, Pekanbaru 28291 Indonesia \\ email : luerdi@univrab.ac.id
}

\begin{abstract}
The ASEAN Agreement on Transboundary Haze Pollution (AATHP) is a collective effort agreed by all of the ASEAN member countries to purposedly tackle haze pollution and Indonesia finally ratified it in late 2014. Indonesian government has had responsibilities to carry out its part to tackle forest and land fires resulting in transboundary haze within its territory since then, coordinating and cooperating with all of its lower-level administrations. However, there has been little attention to the study emphasizing any local government's roles to support the regime's goals. This research paper aims to describe Riau government's policies to realize the goals of the AATHP from 2015 to 2016. This paper applies behavioralist approach, which is effective to analyse the actor's policies or decisions inasmuch as it allows the analysis on an individual or group that represents a state or governance. This paper apllies David Easton's system theory of decision making which belongs to the approach. The finding of the reseach is that Riau government took the policies of creating the plan of action on forest and land fires prevention and raising the local emergency statuses to contribute to the goals realization. It means that the local government was, too, an important actor to determine the success or failure of the regime during the years.
\end{abstract}

Keywords: Policy, AATHP, regime, plan of action, local emergency status.

\section{INTRODUCTION}

Amid the plurality of issues in international relations nowadays, security is still an interesting issue to discuss due to the fact that there has been growing awareness on the need to widen the concept of security since the end of the Cold War [1]. Security is not merely assosiated to the threat of military aspect from any country, otherwise it has already had a wide range of low politics issues then called nontraditional security whose objects are individuals. The actions of international organizations have long been a staple of security studies courses [2]. Less attention has been devoted to analysing a wide range of non-state actors and they can play as the agents of both security and insecurity [3].

Globalization has allowed the thoughts of security to gain a wide meaning and shift from a military dimension to non-military dimensions due to increased interdependence and the complexity of inter-sate relations [4]. The latter, due to the objects of security directed to individuals, is called human security. In human development report issued by UNDP (1994), human security included various security dimensions such as economic security, food security, health security, environmental security, personal security, society security and political security [5].

Environmental security cannot be excluded from the study of international relations nor can it be ignored by any country. By the early twenty-first century, environmental issues had been high on the international agenda for a whole generation of political leaders, government officials, scientists, industrialists and concerned citizens [6]. Since the late 1960s, the awareness of the risks and implications of a wide range of international environmental problems has increased greatly, justifiably so [7]. Furthermore, the issues have been sitting in all the regions of the world and not only developed countries but also developing countries have set the issues into their national agenda settings.

Haze pollution caused by forest and land fires has become a serious threat to human security and an annual outbreak in the region of Southeast Asia generally and Indonesia particularly since 1997 [8]. The fires occured repeatedly with a large range of damages such as environment, economy and human life across 
the region. Indonesia was notorious for the raging fires in a large number of its forests and peatlands, while the Indonesian government seemed to have difficulty putting out the fires alone due to some reasons. Some offers were extended by both ASEAN and its individual members to Indonesia in order to overcome the problem within its territory.

ASEAN realized that the haze pollution could not be tackled by any country alone refering to the previous ineffective experiences. The idea to create a legal framework to allow all parties to reduce the transboundary pollution and its associated harm was finally realized through the AATHP in 2002 [9]. The agreement, so-called the haze pollution regime, has been expected to bring all the ASEAN member countries to continuing, effective cooperations in many aspects to save the region. The regime has been expected to help achieve the vision of free-haze ASEAN by 2020 as well. Surprisingly, Indonesia sharing the most of the region's forests and peatlands as well as fires did not ratify the agreement for twelve years. Indonesia's presence prior to its 2014 ratification at the AATHP Conference of Parties (CoP) had only acted as an observer country [10].

As soon as Indonesia ratified the agreement, the ASEAN leaders and non-govermental organizations appreciated the Indonesian government's official effort to carry out its responsibilities for the issue under the ASEAN's scheme. The 2015 fires within Indonesia's territory which raised confusion, frustration and anger in all levels especially in the local level were the worst after mid-2013 fires [11]. The occurances seemed to be the regime's first challenge after Indonesia's official approval as a part of the AATHP. The regime has required all the member countries to take serious actions through their respective national plan of action as a domestic guideline to realize its goals since its inception. Indonesia already gave its efforts to show its commitment to the agreement during 2015 and 2016.

The fires which raged in Riau in 2013, 2014 and 2015, like previous years, resulted in severe haze pollution within its area. Due to its geographical proximity to other countries such as Singapore and Malaysia, Riau became the attention regarding potential impacts to the neighborhood. Riau, one of its provinces in which fires severely occured at that time, became an object of heated criticisms in the local as well as national level.

However, rarely do academics have concern about the issue in a local context and so do international relations students have very limited academic references in term of local actors regarding this international phenomenon. This paper tries to fill the space. In addition, Indonesia already ratified the agreement and the country has bound itself legally and morally to cope with the haze and cooperate with the rest of the ASEAN member countries, but Indonesia still produced transboundary haze in 2015 [12].

There is a single intended inquiry as a research question in this paper, that is, what policies did Riau government take to realize the goals of the AATHP in the post-ratification (2015-2016)? This paper aims to mainly describe Riau government's policies to support the AATHP's goals. This paper also includes the description of factors causing the local government took such policies, the agreement's goals and forest and land fires as well as haze as threats in Riau province. This paper applies the worldview of behavioralism and David Easton's system theory of decision making which enable to explain why and how the policies were taken by the local government.

This paper has the areas of limitation: (1) it describes the haze pollution as a threat to human security in Southeast Asia, Indonesia and Riau province. For domestic level, the haze-causing factors, forest and land fires, were concerned threats as well, (2) it describes the policies which Riau government took to realize the goals of the AATHP and (3) the period of the phenomenon in this paper is after Indonesia's ratification, exactly from 2015 to 2016 .

This paper shows the finding that Riau government: (1) took the policy of local action plan on fires prevention which was followed by the creation of the 2015 Gubernatorial Regulation, Number 5 and the formulation of key activities in the plan of action and (2) raised the local emergency statuses both emergency preparedness and response which were then supported by the formation the local task force of forest and land fires and haze disaster.

This paper comprises some sections such as introduction, theoritical framework, materials and methodology, results and discussion and conclusion. This paper is definitely unable to give the answer if the policies were effective to support the goals of the AATHP through the implementations during the years. There have to be different analysis to reveal such curiosity. This question can be another project in the future.

Inspite of such limit, this article can be advantageous for international relations scholars, developing the understanding on international relations studies in a local context. 
Apart from filling the gap of the problem, this paper can contribute to the science development since there have been very few resources related to the realization of an international regime in a smaller area than either a state or a region.

\section{THEORITICAL FRAMEWORK System Theory of Decision Making}

The behavioralist approach is applied as a worldview to analyse the research question in this paper. Behaviralism focuses on human behaviors and behavior patterns as actors in politics and governance. Such approach is very useful in explaining any phenomenon which is related to the behaviors of people or groups existing in a state organization. By sticking to the view of this approach, the government of Riau is placed as the actor in this paper.

Alan C. Isaak stated that the function of a theory to explain empirical generalizations gave a scientific theory its strength [13]. A theory is not to be judged true or false, otherwise more useful or less useful as the explanation of empirical laws. Since laws describe knowledge in a particular field, a theory explains the knowledge more generally and more completely, indicating intertwined relations between facts which apparently seem separated [14]. In other words, a theory is a statement or a proposition explaining generalization so that it can be an explanatory tool which relates concepts.

The theory applied in this paper is the political system analysis of David Easton which fits the approach. The political system explained by Easton is a decision making theory which can be applied in the international, national and local level. Easton's theory includes the concept of inputs (demands and supports), political system (the behaviors or actions of authorized actors) and outputs (policies or decisions) to understand how a political system works.

The analysis embraces an asumption that a political system is an individual unit into which persistent inputs flow [15]. The flowing inputs guarantee the system to work continuously. The inputs are turned into outputs by the process in the system, which afterwards influence the system or its environment as well as the inputs through feedbacks [16]. The illustration of Easton's system theory can be seen as follow:

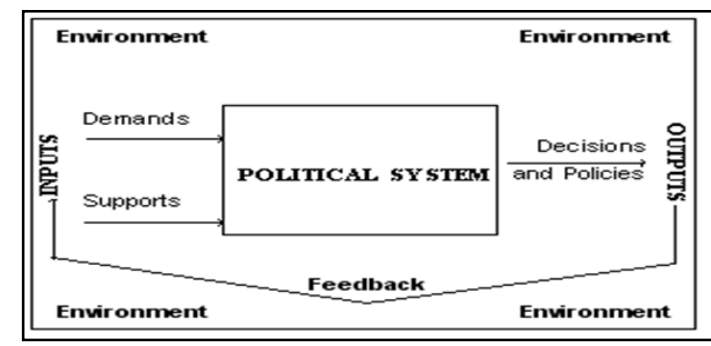

Illustration 1. David Easton's System Theory

Based on the illustration, this paper can explain the decision-making process that involved the authorized government in Riau province regarding the policies made after the AATHP ratification by Indonesia, to realize the goals of the AATHP as follow:

Firstly, the fires which burned the peatlands and forests in Riau in many years and early 2015 caused severe haze pollution across the province besides environmental damages. The haze pollution caused both social and economic losses as well. Many activities of business and people's livelihoods could not run normally due to thick haze pollution. Many people suffered from some haze-caused deseases especially children and women, even some life losses did happen in the province. Schools issued long holiday policies to protect their students from the impacts of the haze pollution [17].

Some local pressure groups ranging from non-governmental organizations and local communities such as Walhi, Jikalahari, Gerakan Riau Melawan Asap, etc and students movements from various higher schools gave pressures to the local government as a grassroot response to the problem [18]. The pressures coming from the various groups highly demanded that the governor with his power immediately found any policy or decision considered the best way to tackle the fires and haze due to their intolerable damages. The demands were expressed in many ways like frequent protests, dialogues and intelectual criticisms in the media. Local media's coverages over the haze pollution and its impacts strengthened the demand. The media's coverages consistently reported forest and land fires in the province and Riau government's slow responses, even its inability.

The Indonesian central government approving and joining the AATHP also criticized the local government in handling the fires and haze. The Indonesian government as the representative of the country in the regional level held national responsibilities to solve the fires and haze polllution within its territory according to the articles of the agreement. Therefore, the government of Riau was 
supposed to take action seriously regarding the problem. Some ministers and even president already visited Riau, which meant another pressure for the local government [19].

Riau annually became one of the fire sources which produced the haze pollution, which also worried neighboring countries. Singapore and Malaysia often expressed their disappointments to the inefective actions taken by either the Indonesian or Riau government to prevent and control the land and forest fires. Such international criticisms were also demands for the local government.

Secondly, despite the pressures or demands, the input came in the form of support from the central government. The Indonesian central government expected Riau government to keep coordinating and cooperating in responding to the problem and its harmful effects and to issue policies urgently needed within its area. The support also came from a wide spectrum of people to the local government to tackle the fires and haze with any measurement. The people expected the local government's serious actions to reduce the fires and manage the risks of haze pollution. So, did the local legislature supported the executive in issuing some necessary policies or decisions as Riau was a part of the national fires and haze problem.

Thirdly, both demands and supports were processed in a box-like political system. The process here was the actor's action or behavior. Riau government as the actor in the system considered itself as a part of national unity which had to work together with its upper-level governance mainly in fires reduction, risks management and possible future prevention within its area by creating local policies or decisions. These were directed for the purpose of domestic need as well the AATHP's realization.

The demands and supports coming from a variety of sides regarding the fires and haze pollution were necessary to consider into actions so that the local government kept gaining trust from the people. As an authorized decision maker, the governor created the plan of action on carrying out the prevention of forest and land fires as well raised the states of emergency in its area. The former was integrated in the 2015 Governor's Regulation, Number 5, while the latter was followed with the formation of a task force of forest and land fires and haze disaster, an ad hoc body which then fought fires and haze pollution. These policies were expected to contribute to the realization the AATHP within its area as demanded by the national government.
The decision making and sequence of the policies can be seen through the following illustrations respectively:

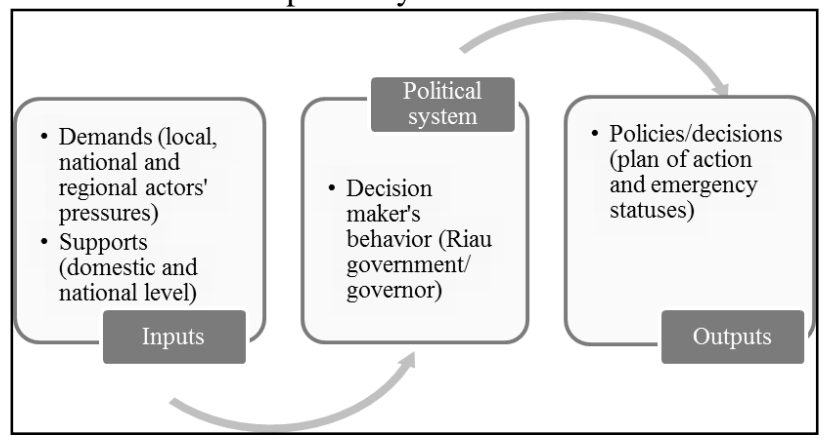

Illustration 2: Decision Making In Riau

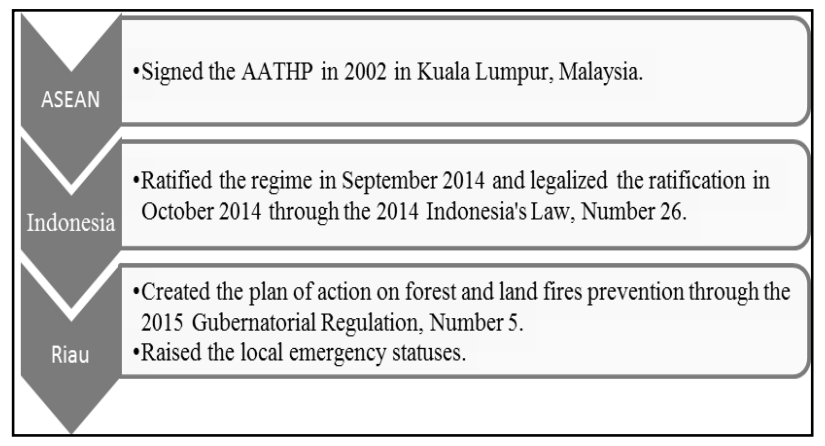

Illustration 3. Sequence of Policies

\section{MATERIALS AND METHODOLOGY.}

The qualitative approach with the analytical descriptive model, in the form of a case study was applied in this paper. Theoritically, the qualitative research begins by defining any general concept, in which experiences change because of the research result that a variable in the research can turn into an outcome [20]. The method could be counted on revealing the facts behind the phenomenon, the Riau government's policies to realize the goals of the AATHP. The method was complemented with the operation of a relevant theory. The technique applied in gathering data was the library research. A variety of data containing relevant information in this paper ranged from books, journals, documents and useful articles. The information gained from the media of internet, many of which were local websites due to the case's locality, was applied, too.

The interactive analysis model of Miles and Huberman to analyse the data was applied in this paper. The model of data analysis consists of some activities: (1) data gathering/collection, (2) data reduction, (3) data display and (4) verification or conclusion drawing. The analysis 
model is called an interactive model since a series of the activities intertwines before, during and after the data gathering in a paralel form to establish general knowledge called analysis, in other words the data gathering activity and other three activities are included in the process of cycle and interaction [21].

While applying this model, the researchers should shift from one activity to the other ones, starting from the process of data gathering, data reduction, data display and verification. Therefore, the analysis conducted was a series of process activities which repeatedly and constantly occured and the activities followed each other. The activities only stopped after a complete report of this paper was finished. The illustration of interactive analysis model of Miles and Huberman can be seen as follow:

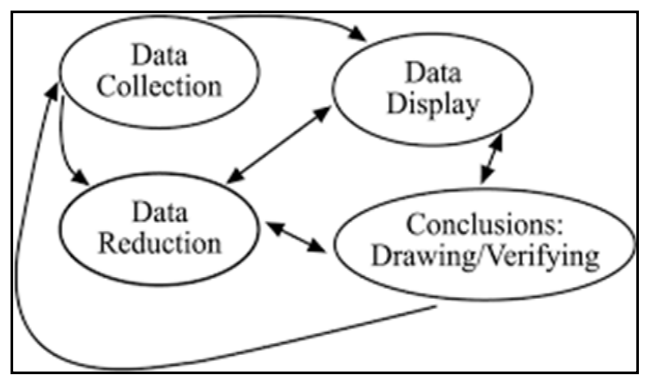

Ilustration 4. Miles and Huberman's Interactive Model

By refering to the interactive model, the steps passed while conducting the research in this paper were: firstly, while in the data gathering stage, as much as information relevant to the phenomenon was searched with the technique already decided. A number of critical questions were made related to the main topic. In this case, the data related to the ASEAN Transboundary Haze Pollution and its realization in the local context were searched and then some questions regarding the issue were raised in order to ease in conducting data reduction.

Secondly, while in the data reduction stage, the roughly collected data were considered, simplified and transformed. Sorting and choosing the information relevant to the topic were then conducted and so was discarding or saving the information considered unnecessary. Not only should data reduction process be done when many data were already collected, otherwise it could be done since the beginning of the research, despite their limited availability.

However, searching for more complete data was definitely still necessary to help determine the research question. As the data gathering process was still continuing, so the data reduction process was continuing as well. In this stage, the policies that Riau government took after Indonesia's ratification began to be focused along with the causing factors. Meanwhile, irrelevant information was taken aside.

Thirdly, data display was defined as a collection of displayed information which allowed the possibility of conclusion drawing and actions taking. While in this stage, what happened and what had to do could be understood more easily with the data display. An analysis could be extended and actions could be taken by deepening the findings. In this case, the local government's policies to realize the goals of the AATHP after Indonesia's ratification began to show up. Nevertheless, the data collection was still necessarily conducted to strengthen such findings and so was the data reduction.

Fourthly, verification or conclusion drawing was defined as the drawing of data meaning previously displayed based on what was understood and interpreted. From early data gathering, the meaning began to be searched and the order, explanatory patterns, possible configuration, events sequence and proposition began to be recorded. The conclusion drawn at the beginning was not clear, but it improved to be more subtle and had a strong foundation afterwards. In this research, during the process of data collection, reduction and display - all of which were conducted interactively, reversibly and cyclically, in which they caught up with each other - the conclusion was finally verified that Riau government took the action plan policy and local emergency states policy.

\section{RESULTS AND DISCUSSION AATHP and Its Goals}

The AATHP is basically one form of the commitment implementations to the aims and purposes of the Association of Southeast Asian Nations or ASEAN as set forth in the Bangkok Declaration of 8 August 1967, in particular to promote regional cooperation in Southeast Asia in the spirit of equality and partnership and thereby contribute towards peace, progress and prosperity in the region [22]. This basic commitment is clearly stated in the agreement that has been signed by all of the ASEAN member countries.

The AATHP was initially signed by ASEAN member countries including Indonesia in Kuala Lumpur, Malaysia in 2012 and it came into force in 2013 after six ASEAN member countries' ratifications [23]. However, 
Indonesia only ratified the agreement 12 years later, being the last signatory after experiencing a series of bad fires and haze pollution disaster as well as neighborhood protests and domestic outcries. Indonesia's ratification, which had been previously signed by the Indonesia's legislature, environment ministry, foreign affairs ministry and law and human rights ministry on 16 September 2014, officially legalized by Indonesia's government through the Indonesia's 2014 Law, Number 26 on the Ratification of the ASEAN Agreement on Transboundary Haze Pollution [24]. The Indonesia's instrument of ratification was deposited to ASEAN secretary general on 20 January 2015 afterwards [25].

Though the agreement is considered legally binding for all of its member countries, ASEAN cannot force any of which to take particular measurements in case of fires and haze in its territory. ASEAN recognizes and upholds the sovereignty of the member countries by entrusting them to tackle the problems nationally, instead of regionally. Only with the approval and request of the country national government can regional actions be taken. Indonesia's fires in 2015 can be the example, in which Indonesia's government prefered national measurements to regional ones. ASEAN's principles such as non-interference and consensus building which have constantly become the foundation of ASEAN way until today prevail in its products, including the AATHP.

The regime consists of 6 parts with 32 articles and 1 annex, which includes such a range of items as general provisions, monitoring, assessment, prevention and response, technical cooperation and scientific research, institutional arrangements, procedures and final clauses [26]. All of the items are based on partnership, solidarity and mutual understanding of the ASEAN member countries inspired by United Nations' charter and international law principles.

The goals of the AATHP are stated in article 2 on objective: to prevent and monitor transboundary haze pollution as a result of land and/or forest fires which should be mitigated, through concerted national efforts and intensified regional and international cooperations [27]. Then it is also stated that it should be pursued in the overall context of sustainable development and in accordance with the provisions of the agreement [28]. From such article, it has always been interpreted that national efforts will be put prior to regional cooperations to face fires and haze events in the region.

\section{Forest and Land Fires and Haze as Threats in Riau}

The forest and land fires followed by haze for many years gave lots of implications to Riau, not only to the local government but also to people and environment. There had been some implications experienced by the province such as environmental damages and pollution, health problems, economy and bilateral relationship. The implications can be seen as follow [29]:

Table 1. Implications of Forest and Land Fires in Riau

\begin{tabular}{|l|l|l|}
\hline No & Implication & Indicator \\
\hline 1 & $\begin{array}{l}\text { Environmental } \\
\text { damages and } \\
\text { pollution }\end{array}$ & $\begin{array}{l}\text { Decreased forest and } \\
\text { peatland resource, } \\
\text { decreased rand } \\
\text { fertility, decreased } \\
\text { function of forests } \\
\text { ecology, decreased } \\
\text { biodiversity, damaged } \\
\text { air and water quality, } \\
\text { increased glasshouse } \\
\text { effect. }\end{array}$ \\
\hline 2 & Health problems & $\begin{array}{l}\text { Respiratory deseases, } \\
\text { ocular irritation, blood } \\
\text { poisoning, skin } \\
\text { deseases. }\end{array}$ \\
\hline 3 & Economy & $\begin{array}{l}\text { Bothered social and } \\
\text { economic activities, } \\
\text { bothered tranportation } \\
\text { activities, bothered } \\
\text { educational activities. }\end{array}$ \\
\hline 4 & $\begin{array}{l}\text { Bilateral } \\
\text { regional and } \\
\text { relationship }\end{array}$ & $\begin{array}{l}\text { Transoundary haze } \\
\text { pollution, irritated } \\
\text { relationship with } \\
\text { neighborhood } \\
\text { countries }\end{array}$ \\
\hline
\end{tabular}

Based on the record, Riau suffered from a large number of forest and land losses for many years. There was a trend of increased fires from 2011 to 2014 in the forests and lands of Riau. The width of burnt forests and lands during those years can been as follow [30]:

Table 2. Recapitulation of Forest and Land Fires' Width in Riau

\begin{tabular}{|l|l|l|l|l|}
\hline Year & 2011 & 2012 & 2013 & 2014 \\
\hline $\begin{array}{l}\text { Hectare } \\
\text { (ha) }\end{array}$ & 74.50 & $1,060.00$ & $1,077.50$ & $6,301.10$ \\
\hline
\end{tabular}

Besides, the fires in Indonesia mostly occured in peatlands which left the areas not to 
be easily extinguished. This condition contributed to haze pollution in the country, including in Riau. More than 50 percents of peatlands in Sumatera are in the province. Here are the distribution of peatlands in Riau based on its depth [31]:

Table 3. Distribution of Peatlands in Riau Based on Its Depth

\begin{tabular}{|c|c|c|c|c|c|}
\hline \multirow{2}{*}{$\begin{array}{l}\text { All } \\
\text { Sub- } \\
\text { regions }\end{array}$} & \multicolumn{4}{|c|}{ Peatland Depth (in cm) } & \multirow[t]{2}{*}{ Total } \\
\hline & $<100$ & $\begin{array}{l}100- \\
200\end{array}$ & $\begin{array}{l}200- \\
300\end{array}$ & $>300$ & \\
\hline$\stackrel{\overrightarrow{0}}{\stackrel{0}{E}}$ & $\begin{array}{l}0 \\
\text { Un } \\
+ \\
0 \\
N \\
\end{array}$ & 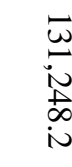 & 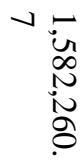 & 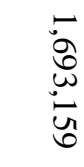 & 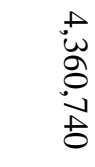 \\
\hline
\end{tabular}

Due to the experience that the forest and land fires were inevitable each year and worsened by haze, they have been becoming threats for the province. Riau government was always getting pressures because of these events. Moreover, Riau was often identified as one of the national critical areas with abundant hotspots which attracted national government's attention. It had plenty of fire-prone areas even until the villages with limited resources to control the fires which then caused haze pollution last few years. Here are the fire-prone areas in Riau recorded by the government [32]:

Table 4. Fire-Prone Areas in Riau

\begin{tabular}{|l|l|l|l|}
\hline No & $\begin{array}{l}\text { Sub- } \\
\text { region/municipality }\end{array}$ & $\begin{array}{l}\text { Number } \\
\text { of } \\
\text { districts }\end{array}$ & $\begin{array}{l}\text { Number } \\
\text { of } \\
\text { villages }\end{array}$ \\
\hline 1 & Siak & 7 & 15 \\
\hline 2 & Rokan Hilir & 4 & 11 \\
\hline 3 & Kepulauan Meranti & 2 & 18 \\
\hline 4 & Bengkalis & 4 & 33 \\
\hline 5 & Indragiri Hilir & 10 & 38 \\
\hline 6 & Dumai & 3 & 11 \\
\hline 7 & Indragiri Hulu & 5 & 17 \\
\hline 8 & Pelalawan & 5 & 26 \\
\hline \multicolumn{2}{|l|}{ Total } & 40 & 169 \\
\hline
\end{tabular}

\section{Riau Government's Policies to Realize the AATHP's Goals}

The central government emphasized the important roles of local governments' efforts, especially those whose areas of forests and lands hosted a large number of hotspots and resulted in severe haze. Riau government was one of them, included in the national policy in preventing and countermeasuring such problem. The domestic situation and international response followed this consideration and with which the local government took the policy of creating the plan of action on the prevention and raising the local statuses of emergency. In order to ease the coordination among stake holders in conducting the two policies, the governor instructed to reactivate the provincial post of disaster prevention and control based in Lanud Roesmin Nurjadin Pekanbaru [33].

\section{Plan of Action on Forest and Land Fires Prevention \\ Issued the 2015 Gubernatorial Regulation, Number 5}

The plan of action made by Riau government was the prevention effort to minimize the future potential of forest and land fires. The decreased fires would be expected to affect the damage of haze pollution effectively. In order to strengthen the effort of prevention, Riau government officially legalized the plan of action into a legal reference and framework through the 2015 Riau Gubernatorial Regulation, Number 5 on the Prevention of Forest and Land Fires in Riau Province, on 2 February 2015 [34].

The regulation was handed out to all chiefs of sub-region and mayors across the province at the launching event of the action plan and coordination meeting with the minister of living environment and forestry on 16 February 2015 [35]. The meeting was an initial action to implement the prevention action plan. Furthermore, the evaluation and responsive actions to face the ongoing fires and haze were the subjects of the coordination as well.

The regulated plan of action created by Riau government engaged the involvement of central government, sub-ordinate local governments, communities and corporations in across the province. The plan of action covered 9 objectives as stated in article 3 of the regulation: (1) fix the protection policy in fire-prone areas, (2) conduct the evaluation related to the width of corporate consessions managed by corporations whose areas were burnt, (3) improve local governments' capacity in conflict resolution, (4) strengthen the information system of forest and land fires, (5) strengthen legislation to the prevention of forest and land fires, (6) improve the layered monitoring system, (7) empower communities to increase their awareness of fires in fire-prone areas, (8) improve support to the activities of zero-burning clearance and incentive rewarding and (9) ensure sufficient funding for the prevention of 
forest and land fires in the Local Budgeting of Revenue and Expense (APBD) [36].

While the main points of the policy, which were the concrete actions, were the intertwined agenda among the governances under an umbrella of the provincial action plan. The action plan consisted of 16 breakdowns of the above objectives which were targeted to complete by the end of 2015 [37].

\section{Formulated Key Activities in the Action Plan}

Besides the existence of the gubernatorial regulation, the policy of creating the plan of action on the prevention can be seen from the roles of Riau government in strengthening the policy by formulating the key activities to commit the prevention efforts. Regardless the debate over its success or failure, Riau government did the actions to implement the key activities of the action plan, even though not entirely very successfully. Two most successful implementations were contructing thousands of canal blocks and forming hundreds of local communities almost in whole villages who could be relied on both preventing and fighting fires, as local resources.

Canal blocking, as a long-term prevention effort, actually had begun before the action plan's inception. However, through the action plan it was made the urgent local program in all levels of governance in the province. Canal blocks could be useful to maintain the storage of water in peatland areas especially during dry seasons so that the areas stayed wet. The local government motivated the corporations operating in the province to contruct them as well [38].

Local communities called Community Cares of Fire were created in prone-fire areas. Like canal blocking, this program was not new but the local government got its moment to extend the number of the communities after Indonesia ratified the AATHP. The governor's regulation became a legal responsibility for sub-regional governments to push the creation of such communities in the villages within their administrations. These communities were provided with some trainings, not only by the local goverments but also by corporations to prevent fires and use equipment to put out fires since the beginning [39]. Creating such local communities was intended to disseminate awareness to people towards fires and haze and invite them to participate in term of the prevention and early fighting of fires in the lowest spectrum of society.

Riau government actually had formulated 16 key activities in the action plan, including the construction of canal blocks and local society empowerment. The formulated activities can be seen as follow [40]:

Table 5. Key Activities of Action Plan

\begin{tabular}{|l|}
\hline Key activities \\
a. Include inner peatlands as protected areas
\end{tabular} in the provincial, sub-regional and municipal site plan (RTRW).

b. Patronize and supervise corporate concession holders, especially those in inner peatland areas.

c. Ensure the corporations to possess water management to keep peatlands wet in order to prevent forest and land fires.

d. Establish the canal blocks to maintain peatlands' wet and prevent fires in Sungai Tohor (Tohor River).

e. Do evaluation towards the width of corporate concessions whose areas were burnt.

f. Improve local governments' capability to solve conflicts in 17 audited object concessions.

g. Build the integrated information system of forest and land fire monitoring system BP REDD+, ministry of forestry and living environment's fire-prone map and early warning system of forest and land fires seasons of BP RED+.

h. Make the local governments' regulations (province/ sub-regions/ municipalities) which regulate all of the detailed aspects on the prevention of forest and land fires.

i. Strengthen the system and institutions which patronize and supervise the corporate concession holders as well as optimize the coordination system of prevention and countermeasure of forest and land fires.

j. Commit administrative law enforcements to the corporations which ignored the audit result recommendations.

k. Create the reguler evaluation system on the implementation of the audit result recommendations.

1. Create and empower the Community Cares of Fires (MPA) in each fire-prone area.

m. Provide the requisites and prerequisites of zero-burning clearence for communities with economical technology.

n. Reward some incentive for those conducting the zero-burning clearance.

o. Provide sufficient particular budget and budgeting access in the provincial/ subregional/ municipal Local Budgeting of Revenue and Expense (APBD) for the prevention purpose (not only fires fighting). 
The local government seemed not to be able to implement all of the key actions, but some based on the target stated in the governor's regulation by the end of 2015 . That fires and haze in Riau still became national problem during 2015 could be a reason for such hyphothesis. While more budget was really needed to prevent and control fires at that time, the local government admitted that the budget did not suffice [41]. However, the case might have differed in 2016.

\section{Local Emergency Statuses \\ Declared the State of Emergency Preparedness and Response}

While the plan of action policy was the local effort to prevent the forest and land fires, the decision of raising the state of emergency preparedness was the one to handle the ongoing fires. By declaring the status, Riau government warned the people to be aware of forest and land fires. The decision was issued on 25 February 2015 through the Riau Gubernatorial Decision (116/II/2015) [42]. It was the first emergency preparedness in the post-ratification of the AATHP, however not the first time in forest and land fires history in the province. The same decisions were declared several times during 2015 and 2016 through the various gubernatorial decisions.

Besides the state of emergency preparedness for forest and land fires, Riau government raised the state of emergency response for haze disaster as well. The decision was finally issued only after the haze pollution was getting further more worsening and the local government was getting a lot more huge insists from domestic level [43]. The 2015 haze was much more terrible than those in the previous years, however the local government did not take immediately required actions to respond to haze pollution since the causing factors, the fires, came from the neighbor provinces, not within Riau [44].

The late decision of emergency response for haze disaster was issued on 14 September 2015 when the local pollutant index exceeded the maximum level of 350 psi (pollutant standard index), reaching 948 to 1,100 psi [45]. Though the status was initiated to respond to the severe haze, the actions were also purposely to fight fires and prevent the future potentials. The emergency response decision was followed by some actions taken by the local task force such as establised as many health posts as possible to prevent health problems caused by haze, improved the fire fighting activities by sending more resources to the fire-prone areas, isued holidays for educational activities and shortened working hours [46].

\section{Formed the Task Force on Forest and Land Fires and Haze Disaster}

The decisions to declare emergency status were followed by the formation of the local task force on forest and land fires and haze disaster that was entrusted to fight fires and control the impacts. The first-2015 task force was formed through the Gubernatorial Decision (117/II/2015) on the same day of the emergency preparedness declaration [47]. The task force was the combination of official elements such as Local Agency for Disaster Countermeasure (BPBD), National Police (Polri), National Army (TNI), Manggala Agni, communities and other local institutions [48].

Like the status of emergency preparedness, such task force had been formed several times during 2015 and 2016. Riau government disbanded the ad hoc body when the situation was becoming better and the most recent disbandment was committed in November 2016 following the status revocation due to the reduced hotspots and monsoon period [49]. During the years, the task force did its roles such as conducted the technique of weather modification, put out fires with water bombing from the air, put out fires on the ground, investigated the offences resulting fires by corporations and community members and responded to the risks caused by fires and haze [50].

\section{CONCLUSION}

The policies that Riau government made were the result of connections among subsystems. The pressures coming from the local, national and regional actors became the Riau decision maker's considerations, in this paper, Riau government or governor. Creating the plan of action and raising the local emergency statuses, which were the local government's policies, were the outputs of the existing political system. The yearly forest and land fires have been serious events in the national and local level. While the haze resulted in by fires has brought transboundary haze pollution as a regional issue and threat for the region of Southeast Asia.

The success and failure of the AATHP could be determined by the local policies as well now that the local government's roles were needed to realize the regime's goals within its area. This paper shall leave a question that can be an interesting topic in the future project, that is, whether the plan of action created by Riau 
government along with other policies related to forest and land fires was effective to support the AATHP's goals. The implementation of the regulation's key activities needs examining in the project.

This paper definitely has some shortcomings, for instance the data already employed in this paper only ranged from secondary sources. It should be supported by the primary data like interview results with the local decision makers. Besides, hardly did this research refer to the previous literatures or researches related to the implementation of an international regime in a local context due to the scarcity of resources. However, this paper contributes to fill the gap and benefits those who are interested in politics and international relations, especially studying international regime and non-traditional security issues.

\section{REFERENCE}

[1] Swanström, Niklas., 2010, 'Traditional and NonTraditional Security Threats in Central Asia: Connecting the New and the Old', in China and Eurasia Forum Quarterly, Vol 8, No. 2, Central AsiaCaucasus Institute \& Silk Road Studies Program, p. 35 .

[2] William, Paul D., 2008, 'Security Studies; An Introduction', in Security Studies, ed. Paul D. William, Routledge, UK, p. 9-10.

[3] Ibid.

[4] Winarno, Budi., 2014, Dinamika Isu-isu Global Kontemporer, Central of Academic Publishing (CAP), Yogyakarta, p.9.

[5] 'UNDP, Human Development Report, 1994', in Budi Winarno., ibid.

[6] Greene, Owen., 2001, 'Environmental Issues', in Globalization of World Politics; An Introduction to International Relations, 2nd Edition, ed. John Baylish and Steve Smith, Oxford University Press, Oxford, p. 387.

[7] Ibid.

[8] 'ASEAN Agreement on Transboundary Haze Pollution: The Indonesian Commitment',

$<$ http://asc.fisipol.ugm.ac.id/aseanagreement-on-transboundary-hazepollution-the-indonesian-commitment/> [accessed on August 10, 2016].

[9] Jr, David B. Jerger., 2014, 'Indonesia's Role in Realizing the Goals of ASEAN's Agreement on Transboundary Haze Pollution', in Sustainable Development Law \& Policy 14, No. 1, the Washington
College of Law Journals \& Law Reviews, Washington, p. 35.

[10] Heilmann, Daniel., 2015, 'ASEAN Agreement on Transboundary Haze Pollution and Its Effectiveness As a Regional Environmental Governance Tool', in The Journal of Current Southeast Asian Affairs 3, GIGA German Institute of Global and Area Studies, Institute of Asian Studies and Hamburg University Press, p. 48.

[11] 'Singapore closes schools and slams Indonesia over its hazardous-level smoke haze response', September 25, 2015, <http://www.abc.net.au/news/2015-0925/singapore-hits-out-at-indonesia-ashazardous-haze-shuts-schools/6805322 >, [accessed on August 16, 2016].

[12] 'ASEAN Agreement on Haze? As Clear as Smoke', October 10, 2015, <http://www.ipsnews.net/2015/10/aseanagreement-on-haze-as-clear-as-smoke/>, [accessed on August 10, 2016].

[13] Isaak, Alan C., 1981, Scope and Method of Political Science; An Introduction to the Methodology of Political Inquiry, Third Edition, The Dorsey Press, Illinois, p. 171.

[14] Ibid., p.172.

[15] Easton, David., 2008, 'Analisis Sistem Politik',, in Perbandingan Sistem Politik, ed. Mohtar Mas'oed and Collin MacAndrews., Gajah Mada University Press, Yogyakarta, p. 5.

[16] Ibid.,

[17] 'Udara Pekanbaru Berbahaya, Senin Ini Sekolah Diliburkan', March 24, 2014 <http://riaupos.co/44216-berita-udarapekanbaru-berbahaya,-senin-ini-sekolahdiliburkan-.html\#.WF9uRbmzFuE>, [accessed on November 1, 2016].

[18] 'Kue HUT Kabut Asap Riau Ke 17 Ditiup Sekdaprov', March 14, 2016, <http://riauaktual.com/berita/detail/6255/ku e-hut-kabut-asap-riau-ke-17-ditiupsekdaprov .html\#.WF9vXbmzFuE>, [accessed on November 1, 2016].

[19] 'Jokowi to directly observe handling of land, forest fires in Riau', November 23, 2014, <http://www.thejakartapost.com/news/2014 /11/23/jokowi-directly-observe-handlingland-forest-fires-riau.html>, [accessed on November 1, 2016].

[20] Idrus, Muhammad, 2009, Metode Penelitian Ilmu Sosial; Pendekatan Kualitiatif dan Kuantitatif, Edisi Ke-dua, Penerbit Erlangga, Jakarta, p. 21.

[21] Ibid., p. 148 
[22] Document 'The ASEAN Agreement on Transboundary Haze Pollution', p. 1, <http://haze.asean.org/?wpfb dl=32>, [accessed on August 15, 2016].

[23] 'Indonesia Deposits Instrument of Ratification of the ASEAN Agreement on Transboundary Haze Pollution', January 20 , 2015 , $<$ http://haze.asean.org/2015/04/indonesiadeposits-instrument-of-ratification-of-theasean-agreement-on-transboundary-hazepollution>, [assessed on November 20, 2016].

[24]Document 'The Indonesia's 2014 Law, Number 26', p.2 (Indonesian version: UU RI No.26 Tahun 2014), <www.hukumonline.com>, [accessed on September 30, 2016].

[25] 'Indonesia Deposits Instrument of Ratification of the ASEAN Agreement on Transboundary Haze Pollution', loc.cit.,

[26]Document 'The ASEAN Agreement on Transboundary Haze Pollution', op.cit., p. $1-24$.

[27] Ibid., p. 4.

[28] Ibid.,

[29] 'Pengendalian Kebakaran Hutan dan Lahan di Propinsi Riau' Pemerintah Propinsi Riau, <http://dinaskehutanan.riau.go.id/tag/penge ndalian-karhutla/>, [accessed on December 10, 2016].

[30] 'Rekapitulasi Luas Kebakaran Hutan dan Lahan (Ha) Per Provinsi Di Indonesia Tahun 2011-2016', Direktorat PKHL Kementrian Lingkungan Hidup Dan Kehutanan RI, <sipongi.menlhk.go.id>, [accessed on 12 December 2016].

[31] 'Pengendalian Kebakaran Hutan dan Lahan di Propinsi Riau', loc.cit.

[32] Ibid.,

[33]'17 Tahun Riau Terbakar, Pergub Rencana Aksi Pencegahan Karhutla Baru Tahun Ini Diluncurkan', February 16, 2015, <https://www.goriau.com/berita/umum/17tahun-riau-terbakar-pergub-rencana-aksipencegahan-karhutla-baru-tahun-inidiluncurkan.html >, [accessed on December 10, 2016].

[34]Document 'The 2015 Riau Gubernatorial Regulation, Number 5, p. 6, (Indonesian version: Pergub No.5 Tahun 2015), <http://jdih.riau.go.id/?page=tampilproduk $\underline{\text { \&id=admin/assets/produkhukum/produkhu }}$ kum_1466393477.pdf\&idp=ID_146639347 7>, [assessed on December 10, 2016].

[35]'17 Tahun Riau Terbakar, Pergub Rencana Aksi Pencegahan Karhutla Baru Tahun Ini Diluncurkan', loc.cit., 'Menteri LHK Minta
Kasus Karhutla Riau Diselesaikan', February 17, 2015, $<$ http://ranahriau.com/berita-840-menterilhk-minta-kasus-karhutla-riaudiselesaikan.html\#sthash.98BWZaL3.dpuf> , [accessed on December 10, 2016].

[36] Document 'The 2015 Riau Gubernatorial Regulation, Number 5', op.cit, p. 1.

[37] 'Article 4 and attachment', ibid.,

[38] 'Pembuatan Canal Blocking dan Embung, Pangdam 1/BB Apresiasi PT RAPP', February 23, 2016, <http://riaumandiri.co/mobile/detailberita/3 0744/pangdam-1/bb-apresiasi-ptrapp.html >, [accessed on December 28, 2016].

[39] 'Saat Perusahaan di Riau dan Masyarakat Peduli Api Bersiap Melawan Musim Asap', June 3, 2016, <https://news.detik.com/berita/3225050/saa t-perusahaan-di-riau-dan-masyarakatpeduli-api-bersiap-melawan-musim-asap>, [accessed on December 28, 2016].

[40][36] Document 'The 2015 Riau Gubernatorial Regulation, Number 5', loc.cit.

[41] 'Tak Mampu Atasi Karhutla, LAM Riau Nilai Pergub 2015 Lemah', January 29, 2016,

<http://riausky.com/mobile/detailberita/467 6/tak-mampu-atasi-karhutla,-lam-riau-nilaipergub-2015-lemah.html>, [accessed on December 28, 2016].

[42] 'Pengendalian Kebakaran Hutan dan Lahan di Propinsi Riau', loc.cit.

[43] 'Saatnya Susun Manajemen Bencana Asap' September 25, 2015, <http://kabar24.bisnis.com/read/20150925/ 15/475886/saatnya-susun-manajemenbencana-asap>, [accessed on December 19, 2016].

[44] Ibid.,

[45] Ibid.,

[46] 'Inilah Empat Butir Riau Tanggap Darurat Asap', September 14, 2015, <http://www.riauonline.co.id/2015/09/14/st atus-riau-tanggap-darurat-asap $>$, [accessed on December 18, 2016]

[47] 'Pengendalian Kebakaran Hutan dan Lahan di Propinsi Riau', loc.cit

[48] 'Riau Hentikan Satgas Karhutla Akhir November', November 12, 2016, <http://www.republika.co.id/berita/nasional /daerah/16/11/12/ogj2h4365-riau-hentikansatgas-karhutla-akhir-november>, [accessed on December 10, 2016].

[49] 'Satgas Karhutla Riau Resmi Dibubarkan', November

24 ,

2016 , 
$<$ http://www.antarariau.com/berita/82117/s atgas-karhutla-riau-resmi-dibubarkan>, [accessed on December 17, 2016].
[50] 'Pengendalian Kebakaran Hutan dan Lahan di Propinsi Riau', loc.cit, 